\title{
Employee Shareholding and the Opportunity Cost of Lending Funds: An Empirical Study in the Context of French Companies in the SBF 250
}

\author{
Sara Elouadi, Researcher Professor, \\ FSJES of Ain Sebaa, Hassan II University of Casablanca.
}

\begin{abstract}
Considering trust as a universal mechanism of governance inherent in any cooperation. Our study proposes to invest a new facet of employee ownership. Indeed, the participation of employees in the capital of their businesses, by trust it induces, is likely to limit the uncertainty and distrust of resource providers. To test this relationship, we conducted two empirical studies. The first is to study the structure ratios and liquidity of companies in the SBF 250, in a longitudinal sample of 2001 to 2009. The second study provides a comparison of a matched cross sectional sample, on the score of Altman 19 pairs businesses.
\end{abstract}

Keywords: employee shareholding, opportunity cost, confidence, score Altman.

Employee ownership is having great growth in Europe and France is the European leader in the distribution and democratization of Employee Shareholding. According to the survey carried out by (Eres 2015), $80 \%$ of respondents French companies offer employee shareholding plans against only $47 \%$ in Europe. Similarly, $44 \%$ of French employees are shareholders in their companies against only $26 \%$ in Europe.

In France, the development of employee shareholding is due to a real awareness and a genuine political commitment from the government De Gaulle who initiated the sharing and incentive. France offers, in addition, an incentive legislative framework for the development of employee ownership. Indeed, the law Macron (2015) reduces substantially the conditions for grants and taxation of employee shareholding. To this end, the rate of employer contribution was reduced from 30 to $20 \%$ and employee contribution of $20 \%$ is removed.

Our work suggests a new framework for analyzing the effects of employee share ownership. Indeed, empirical work on employee ownership have invested two main directions. The first became interested in the effects induced by the Employee Ownership on business performance and the second explored the behavioral and attitudinal effects of the property. By introducing trust as a control variable to limit uncertainty and distrust of funds lenders, we propose to study the influence of employee participation in capital lenders interest rates Elouadi (2014).

According to Charreaux and Desbrières (1998), the opportunity cost of money lenders is the minimum price required to undertake the transaction. Based on this definition, we can consider the opportunity cost lenders as the minimum rate of return required by the market. The opportunity cost then depends on the level of risk to lenders of funds. The higher it is more important to be the minimum required return. Our research complements and enriches our previous work on the effects induced by property on organizational attitudes including satisfaction with work and the intention to leave Elouadi (2016) and Elouadi (2015).

\section{Theoretical Framework : Employee Ownership And The Opportunity Cost Lenders}

Trust is the most cost effective solution for shareholders and other stakeholders. It leads to the decline of the control mechanisms set up by the partners. Employee shareholding, for the trust he returns to the market, allows the relaxation of control requirements demanded by corporate partners such credit institutions.

The survey by Ipsos Opinion conducted in June (1999) with a sample of employees, analyzes the motivations and would encourage employees to become shareholders in their company. The results reveal that $91 \%$ of employees say they have chosen employee shareholders for the confidence they have shown in the growth of their businesses. Also, the survey conducted by the (COB Altédia 1999), covering about 150 companies reveals that $72 \%$ of companies believe that employee ownership is a positive sign given to financial communication. Indeed, an employee shareholding policy, expressing mutual trust of employees and leaders in the future of their company, can raise the confidence of financial partners. This reduction of formal protection mechanisms results in a lower required rate. By (Rousseau and al 1993. Zucker 1986), confidence can be a substitute for the monitoring and governance mechanisms to control transactions. As such, Diamonds (1989) explains that the bank proceeded to sort customers based on their reputation to decrease the interest rate. Similarly, Harhoff and Körting (1998) find that mutual trust has a significant negative effect on the interest rate. In turn, Lehmann and Neuberger (2001) argue that the relationship of trust between the banker and the company influences the level of risk assumed by the bank in the credit granting decision. However, as a result of the lack of confidence, Blackwell and Winters (1997) show that the level of interest rate increases with increased 
monitoring efforts by the bank. Allegret and Baudry (1996) represent the operation of the granting of credit as a selling information on future repayment of the loan, and it is this sale allows the company to raise funds. At this level, Fishman and Khanna (1999) note that it is the mistrust that led the bankers to look for information about the companies.

According to Gambetta (1988), trust is linked to the existence of a subjective probability level with regard to the action of the agents. The role of trust is how to reduce this state of uncertainty about the future behavior. For Luhmann (1979), trust is facing the uncertainty and complexity of the evaluation of the actions of agents.

According to Charreaux (1998, p. 10), by relaxing the constraints of control, confidence, leads a priori to a lower cost of control mechanisms implemented by the partners to manage their relationship with the firm. For example, the intervention of confidence in the business banking relationship, reducing the importance of formal protection mechanisms (audit ex ante and ex post collateral taken ...), resulting in a decrease the rate charged.

In addition, research combines trust in financial operations to the reputation capital of the company. Wilson (1985) defines reputation as the assets in which companies and individuals invest. They produce fruit in the short term and positive effects on the long term. Based reasoning by repeated games between $\mathrm{n}$ players, Kreps (1990) notes that the production of trust is based on mediation reputation. This form of trust reminds the concept of "trust-based computing" Rousseau et al. (1998) and the Knowledge-Based Trust Shapiro et al. (1992) and Lewicki and Bunker (1996).

And from Barber (1983), this is a rational choice justified by a favorable presumption of action from the other party that is based on credible information and the reputation. As such, Rousseau et al. (1998) state that the trust can come from a weighted calculation of losses and gains received until an emotional response based on an attachment. The same authors add that this form of trust extends to financial relationships. Retaining computational vision of the trust or the concept of "calculative trust" proposed by Williamson (1993), we conclude then that employee ownership leads to reduce opportunity cost of lending funds from trust it returns to the market. From our theoretical reasoning, we propose to test the following relationship:

H1: Trust established by employee ownership reduces the opportunity costs of lenders

\subsection{The operationalization of the variable trust}

\section{An Empirical Approach}

The hypothesis H1 combines lower opportunity costs of lenders to calculated trust generated by employee ownership. According to Neveu (2004), the calculated trust is based on rational calculation and credible information about the intentions of the other and thus differs from the affective trust. Indeed, in order to make their decision to finance and fix the interest rate, banks must determine ex ante the probability of defaulting on loan. Or the risk that the company will be unable to meet its financial obligations (payment of interest and return of capital) on the scheduled dates.

Heem (2000: 18) defines the counterparty risk for the banker as the risk of non-fulfillment of the financial commitment by the client, that is, in most cases, a loan repayment. The interest rate is thus the remuneration of the risk that the bank takes by lending money. And in the event of uncertainties related to the failure of the company, the bank will decide to increase the rate to compensate for possible hazards. This counterparty risk also refers to the risk of deterioration in the borrower's financial health, which reduces the probability of repayment.

As such, Levratto (1996) states that the physical or legal entity is financed rather than the investment project. Also, it recognizes that the wealth of the borrower plays a fundamental role in the granting of credit. Wealth is then considered as a probative element, when assessing the risk of non-repayment, as such, the value of own funds is a guarantee of the financial independence of the companies vis-à-vis third parties. This strengthens the relationship of trust between the company and the bank, and plays a favorable role when applying for a loan.

As Bernanke and Gertler $(1989,1990)$ point out, the importance of capital reduces the problem of information asymmetry and his cost, which leads to improved credit conditions. Stiglitz (1989) states that increasing net assets increases returns to lenders in the event of bankruptcy and reduces the area of bankruptcy. Also, the combination of these two factors leads to a decrease in the contractual interest rate requested by the lenders (Farmer 1985).

Similarly, Gilles (1992) presents the value of equity as a good indicator of the company's ability to repay its loans. For their part, Calomiris and Hubbard (1990) explain that access to finance varies between firms and depends on the value of their own funds. Levratto (1996) asserts that the ratio of financial autonomy (Equity to Total of the balance sheet) is an indicator of financial soundness and informs about solvency.

Also, Jullien and Paranque (1995) point out that even if the ratio of financial autonomy does not give sufficient information on profitability, it makes it possible to cover the risk. 
In addition, La Bruslerie (1999) summarizes the risk of customer default in two types of events: suspension of payment and insolvency. For Bardos (2001) and according to the criteria of the "Banque de France", companies which have undergone the initiation of collective proceedings are considered to be in default: reorganization or judicial liquidation Pastena and Ruland (1986) justify the financial failure of the firm in an Anglo-Saxon context by the advent of the following three scenarios:

- Where equity is negative;

- When the company can not meet its financial obligations at the time they become due;

- And when the business continues or is liquidated under the protection of a court.

As a result of the work of Wruck (1990) and Opler and Titman (1994), failure is not a sudden occurrence and financial difficulties constitute its enunciator (Bloch, Bourdieu, Colin-Sédillot and Longueville 1994) (Opler and Titman 1994). Numerous researchers have attempted to identify the main accounting indicators capable of detecting signs of difficulties.

On the other hand, the first techniques of forecasting bankruptcy used univariate analysis. These include the Beaver study (1966), its analysis consists in determining for each element of a set of variables a critical value that allows the best discrimination between healthy firms and failing firms. The main criticism made of this method is the contradiction of information revealed by the different ratios.

Moris (1998) adds that it can not be used systematically and does not take into account the possible interactions between the variables. In order to overcome the criticisms of univariate models, multivariate models have emerged with the development of data analysis. The best known discriminant model is that of Altman (1968), using more than one ratio to prevent bankruptcy.

This is the first model that aims to assign a credit score to companies, models derived from the Altman score are widely used by banks in assessing solvency and financial quality of borrowers.

Based on five ratios, Altman determines the following function:

$\mathrm{Z}=0,012 \mathrm{X} 1+0,014 \mathrm{X} 2+0,033 \mathrm{X} 3+0,006 \mathrm{X} 4+0,999 \mathrm{X} 5$

Where:

X1 = Working Capital / Total Assets;

This ratio expresses the importance of working capital in preventing the risk of insolvency of the company. The working capital constitutes a financial security for the company, Altman talks about the most indicative liquidity ratio.

$\mathrm{X} 2$ = Reserves / Total assets;

This ratio concerns cumulative profitability over time, since a company that accumulates large reserves is considered less vulnerable in the event of unfavorable economic conditions.

Altman explains that the age of the company is implicitly taken into account by this ratio. As a result, young firms may be discriminated against by this indicator, because of their low cumulative reserves. And in defending the choice of this ratio, Altman states that, in general, newly created firms are the most threatened by the risk of bankruptcy (Altman 1968: 595).

$\mathrm{X} 3$ = Earnings before interest and taxes / Total assets;

This ratio makes it possible to measure the productivity of the company while neutralizing the tax effect and the debt effect. It makes it possible to estimate the cash flow available to the creditors and shareholders of the company.

X4 = Market capitalization / Total debt;

This ratio measures the ratio of the company's market capitalization to its total debt. The use of market capitalization enriches the analysis by introducing a stock market criterion. Altman notes that this ratio has a higher predictive value of bankruptcy by comparing it to the Common Equity / Total Debt ratio that is commonly used.

X5 = Turnover / Total assets.

This ratio indicates the rotation of the assets, it constitutes a better appreciation of the quality of management of the company and its capacity to be competitive.

In a first analysis Altman fixed at 2.75 the score below which a company is considered to be failing. At the end of this first analysis, Altman's Z score was used to rank 94\% of companies that went bankrupt during the year. New studies were carried out during the period 1969-1999, at the end of which Altman (2000) reduced the $\mathrm{Z}$ score to 1.81. Later and in a different approach, Crutzen and Van Caillie (2007) identify, in their integrator 
model, the most cited theoretical factors leading to bankruptcy chronologically. Their study is a theoretical modeling of empirical work for the prevention of bankruptcy.

The model consists of four chronological steps: the origin of the difficulties, the appearance and deterioration of the symptoms of failure, the red turning of the turn signals and finally the bankruptcy of the company.

Level 1, which focuses on the root causes of difficulties, encompasses five dimensions, including the managerial environment, external environment, corporate resources, management and strategic position

Level 2 related to the symptoms of bankruptcy is characterized by lack of self-financing, lack of liquidity, debt problems and increased financial burdens.

Level 3 encompasses the blinkers of bankruptcy, the decline in solvency and extreme mistrust of lenders. Then, the last level that materializes the advent of bankruptcy. It is characterized by critical nonliquidity and insolvency, inadequate strategic position and ineffective management.

In the absence of a dominant model for assessing corporate failure, the authors recommend using a set of financial indicators. According to the academic literature concerning the risk of default and its relation to interest rate setting, we propose to test the hypothesis of the relationship between employee share ownership and the decrease in lender opportunity costs as follows:

structure and liquidity to assess the liquidity and solvency of companies with employee ownership and others that do not. Then, using the Altman score on a cross-matched sample. Our analysis is at level 2 of the integrating model of Crutzen and Van Caillie (2007) and is characterized by the joint use of two groups of ratios. As such, Van Caillie (2000, p.13) 8 recommends the creation of a set of financial variables reflecting all aspects of management and allowing one to understand the process of changing financial behavior.

The same author suggests using a broad set of financial ratios, subdivided into 2 groups: a static group belonging to the same accounting year and a dynamic group composed of financial ratios resulting from several financial years.

\subsection{Methodology:}

To test the relationship between the financial structure of firms and the opportunity costs of lenders, we opt for a dual empirical material. The first consists of a longitudinal sample covering the structural and liquidity ratios of SBF companies250, for the period 2001-2009.

Indeed, we use the methodology of Allouche et al. (2008). He used the average value of the financial indicators provided by the Diane database for the period 1997-2002 to test the performance and financial characteristics of family and non-family businesses in a matched sample. As such, several authors refer to the importance of longitudinal studies to enrich the empirical results on the relationship between employee ownership and the value of the firm.

Our second empirical material is a matched sample of 38 firms. The analysis relates to the comparison of the Altman scores calculated for the year 2009.

Description of the longitudinal sample

We have downloaded the annual reports of the SBF 250 companies from the year 2001 to 2009. We then obtained a report by company studied. These reports contain all the accounting data and ratios for each of the nine years studied.

We then constructed a first Excel database, on which exist the names of companies and in columns the following elements:

- The 2001-2009 average of structural and liquidity financial ratios.

- Employee share ownership: based on the composition of the IAS FAS Euronext index.

We assigned value 1 to the companies making up the index and 0 to other companies.

- Size: we represented this value by the 2001-2009 average of the total assets of each company studied.

- Sector of activity: we selected the sectors defined, according to the new activity code NAF rev. 2 and which are taken over by the Diane database.

\section{Description of the cross-sectional sample}

The second sample consists of the companies from the SBF 250 and the analysis relates to the calculated Altman score for the year 2009. Our database is made up of an Excel table on which there are in line the names of the companies and In column the following variables:

- $\quad$ Altman score calculated for the year 2009.

- Employee share ownership: on the basis of the composition of the IAS FAS Euronext index, we attributed the value of 1 to the companies making up the index and 0 to other companies.

- Size: we represented this data by the value of the total assets of each company studied.

- Sector of activity: we have selected the sectors defined according to the new activity code NAF rev. 2 and which are taken over by the Diane. 
To compare the Altman scores of the companies studied, we chose the technique of pairing. In this regard, Thietart (1999: 198) recommends using criteria deemed relevant, so as to ensure that the measured effect is derived from the variable (s) studied off the difference in sample composition.

From the empirical literature, it appears that the most commonly used criteria for pairing firms are size and sector of activity. We then obtained 19 pairs of comparable companies in terms of size (total assets) and sector of activity. The following table summarizes the variables used in the analysis of financial indicators.

Table 1: Synthesis of variables

\begin{tabular}{|l|l|}
\hline Variables to compare & $\begin{array}{l}\text { Financial ratios: } \\
\text { - Financial equilibrium } \\
\text { - Financial independence } \\
\text { - Indebtedness } \\
\text { - Financial autonomy } \\
\text { - Degree of depreciation of material assets } \\
\text { - Financing of current assets } \\
\text { - General Liquidity } \\
\text { - Reduced Liquidity } \\
\text { - Score of Altman }\end{array}$ \\
\hline Explanatory variable & $\begin{array}{l}\text { Employee Share ownership } \\
\text { - Membership in the IAS index } \\
0 \text { = company not belonging to the IAS } \\
1 \text { = company belonging to the IAS } \\
\text { - Cotation within the CAC 40, SBF } 120 \text { or SBF } 250 \\
\text { - Employee shareholders representing more than 3\% of the capital } \\
\text { - At least } 25 \% \text { of the staff is an employee shareholder }\end{array}$ \\
\hline Control Variables & $\begin{array}{l}\text { - Size: total assets (average 2001-2009) the longitudinal sample and the total } \\
\text { assets of } 2009 \text { for the cross-sectional sample. } \\
\text { - Sector of activity }\end{array}$ \\
\hline
\end{tabular}

Our final sample is made up of 249 companies and is distributed according to the sector codes of the Diane database. The sector variable is a control variable that will enable us to perform a turnaround in order to constitute a representative sample of the population. We have resumed the sectoral distribution practiced by the Diane base which consists of 7 different sectors of activity: industry; retail business; Wholesale; construction; transport; Services and finally the holding companies.

This sectoral distribution will allow us to classify the companies studied as representative samples in order to allow the comparison of financial indicators. We have ordered the creation of a cross table to visualize the distribution of the sectors on the two types of enterprises studied. At the time of the data capture, we decided to eliminate the Transport sector and to put the companies that belong to it in the Service sector, considering its weak representativeness.

Table 2: Cross-tabulation of Sectoral distribution and employee Share ownership

\begin{tabular}{|l|l|l|l|}
\hline \multirow{2}{*}{ Sector of activity } & \multicolumn{3}{|c|}{ Employee Share Ownership } \\
\cline { 2 - 4 } & Yes & No & Total \\
\hline Wholesale & 0 & 20 & 20 \\
\hline Construction & 0 & 2 & 2 \\
\hline Holding Companies & 10 & 48 & 58 \\
\hline Industry & 3 & 41 & 44 \\
\hline Services & 6 & 113 & 119 \\
\hline Retail business & 0 & 6 & 6 \\
\hline Total & 19 & 230 & 249 \\
\hline
\end{tabular}

According to the table above, the sectors representative of employee share ownership are: industry, holding companies and services. As a result, we will conduct our comparative analysis of the three abovementioned sectors. Our empirical study on financial indicators is split into two samples, the first being a longitudinal sample composed of the SBF 250 companies. The analysis consists of comparing the structure and liquidity ratios observed over the period 2001-2009. The second sample consists of companies from SBF 250, and the analysis is based on the Altman score calculated over the year 2009. Thanks to the sectoral distribution chosen, we were able to establish pairing, making sure to identify for each Company with an employee shareholding an equivalent enterprise belonging to the same sector and having the same size (total assets).

\subsection{Test results from sample 1}

\subsubsection{Empirical test results for the Holding sector}

The following table presents the descriptive statistics for each financial ratio for companies with employee share ownership and the control group. 
Table 3: Descriptive Statistics for the Holding Sector

\begin{tabular}{|l|l|l|l|l|l|}
\hline & ESOP & N & Average & Standard deviation & Error Average standard \\
\hline \multirow{2}{*}{ Reduced Liquidity } & Yes & 5 & 87,970 & 180,966 & 80,930 \\
\cline { 2 - 6 } & No & 41 & 10,360 & 13,388 & 2,090 \\
\hline \multirow{2}{*}{ General liquidity } & Yes & 5 & 88,006 & 180,945 & 80,921 \\
\cline { 2 - 6 } & No & 41 & 10,393 & 13,380 & 2,089 \\
\hline \multirow{2}{*}{$\begin{array}{l}\text { Degree of depreciation of } \\
\text { material assets }\end{array}$} & Yes & 5 & 39,346 & 22,428 & 10,030 \\
\hline \multirow{2}{*}{ Indebtedness } & No & 41 & 51,692 & 19,534 & 3,050 \\
\hline \multirow{2}{*}{ Financial equilibrium } & Yes & 5 & 63,920 & 13,153 & 5,882 \\
\cline { 2 - 6 } & No & 41 & 58,927 & 16,228 & 2,534 \\
\hline \multirow{2}{*}{ Financing of current assets } & Yes & 5 & 1,306 &, 299 &, 134 \\
\cline { 2 - 6 } & No & 41 & 1,441 &, 725 &, 113 \\
\hline \multirow{2}{*}{ Financial independence } & Yes & 5 &, 744 &, 220 &, 098 \\
\cline { 2 - 6 } & No & 41 &, 503 &, 662 &, 103 \\
\cline { 2 - 5 } & Yes & 5 & 62,712 & 14,701 & 6,574 \\
\cline { 2 - 5 } & No & 41 & 58,927 & 16,228 & 2,534 \\
\hline
\end{tabular}

According to the table above, there a difference in averages between the two groups of companies in the Holding sector: There is a positive difference in favor of companies that practice Employee shareholding in relation to general liquidity ratios, reduced liquidity, financial independence and the ratio of net current asset financing. In order to confirm this difference in averages, we performed the Levene test and the test, the results are as follows:

\section{Degree of depreciation of material assets:}

From the table of the Levene test and the t test, it can be seen that the p of the column "Sig" of Levene is equal to 0.54 therefore the test is not significant, and we keep the null hypothesis of the equality of the variances, which is one of the premises of the test of $t$. We will then read the first line of the test $t$ of the equality of the variances which gives $t(44)=-1,32$ with a $\mathrm{p}$ of 0,19 . This degree of significance does not reject the null hypothesis according to which the difference in averages observed between the two groups is compatible with the population difference of 0 .

\section{Indebtedness:}

The Levene test gives a $\mathrm{p}=0.4$ therefore the null hypothesis of the equality of the variances is maintained and the first line of the test $\mathrm{t}, \mathrm{t}(44)=0.66$ is read with $\mathrm{p}=0.19$. We deduce that the difference of the averages is compatible with the population difference of 0 .

\section{Financing of current assets :}

The Levene $\mathrm{p}$ is 0.48 , reading the first line of the test $\mathrm{t}$ gives: $\mathrm{t}(44)=0.8$ with $\mathrm{p}=0.42$. These results do not allow us to reject the null hypothesis.

\section{Financial independence :}

The Levene $\mathrm{p}$ is equal to 0.58 and the first line of the test $\mathrm{t}$ gives $\mathrm{t}(44)=0.5$ with $\mathrm{p}=0.62$. The test does not therefore conclude a significant difference in averages between the two groups.

\section{Financial equilibrium:}

The Levene $p$ is equal to 0.55 and the reading of the first line of the test $t$ gives: $t(44)=-0.4$ with $p=0.7$. So the test is not conclusive to a significant difference in averages between the two groups.

\section{The general liquidity and reduced liquidity ratios:}

The Levene test gives $p=0$ and the reading of the second line of the test $t$ yields the following results: $t(4)=$ 0.96 with $\mathrm{p}=0.4$

So the test is not conclusive to a significant difference in averages between the two groups.

\subsubsection{Empirical Results of the t-Test for the Services Sector}

The following table shows the services sector descriptive statistics for companies that practice employee ownership and the control group. 
Table 4: Services sector descriptive statistics

\begin{tabular}{|l|l|l|l|l|l|}
\hline & Employee Shareholding & $\mathrm{N}$ & Average & Standard deviation & Error Average standard \\
\hline \multirow{2}{*}{ General liquidity } & Yes & 6 & 15,1567 & 19,47677 & 7,951 \\
\cline { 2 - 6 } & No & 112 & 4,5230 & 5,61537 &, 530 \\
\hline \multirow{2}{*}{ Reduced Liquidity } & Yes & 6 & 15,0650 & 19,54804 & 7,980 \\
\cline { 2 - 6 } & No & 112 & 4,4552 & 5,64371 &, 533 \\
\hline \multirow{2}{*}{$\begin{array}{l}\text { Degree of depreciation of } \\
\text { material assets }\end{array}$} & Yes & 6 & 58,2400 & 14,75313 & 6,022 \\
\cline { 2 - 6 } Indebtedness & No & 110 & 55,0233 & 18,12488 & 1,728 \\
\cline { 2 - 6 } & Yes & 6 & 49,8667 & 15,40127 & 6,287 \\
\cline { 2 - 6 } & No & 112 & 50,7392 & 46,54669 & 4,398 \\
\hline \multirow{2}{*}{ Financing of current assets } & Yes & 6 &, 4133 &, 75447 &, 308 \\
\cline { 2 - 6 } & No & 112 &, 3763 &, 58728 &, 055 \\
\hline \multirow{2}{*}{ Financial independence } & Yes & 6 & 1,2883 &, 20253 &, 082 \\
\cline { 2 - 6 } & No & 112 & 1,6093 & 1,22860 &, 116 \\
\cline { 2 - 6 } & Yes & 6 & 49,866 & 15,401 & 6,287 \\
\hline
\end{tabular}

The comparison table of the averages between the two groups of companies shows a positive difference between the general liquidity ratios, the reduced liquidity, the Degree of depreciation of material assets and the financing of assets in favor of companies that practice Employee shareholding. In order to test the reliability of these averages differences, we performed the Levene test and the t test, the results are as follows:

\section{Degree of depreciation of material assets}

From the table of the Levene test and the test $t$, we note that the $\mathrm{p}$ of the sig of Levene is equal to 0.44 , we will then read the first line of the test t of the equality of the variances which gives $t(114)=0.43$ with a $p$ of 0.67. This degree of significance does not reject the null hypothesis that the average difference observed between the two groups is compatible with the population difference of 0 .

\section{Indebtedness ratio}

The Levene test gives a $p=0.59$ so the null hypothesis of the equality of the variances is maintained and the first line of the test $\mathrm{t}, \mathrm{t}(116)=-0.046$ is read with $\mathrm{p}=0.96$. We deduce that the difference of the averages is compatible with the population difference of 0 .

\section{Financing of current assets}

The Levene $\mathrm{p}$ is equal to 0.48 , the reading of the first line of the test $\mathrm{t}$ gives: $\mathrm{t}(116)=0.15$ with $\mathrm{p}=0.88$. These results do not allow us to reject the null hypothesis.

\section{Financial independence ratio:}

The Levene $p$ is equal to 0.59 and the first line of the test $t$ gives $t(116)=-0.046, p=0.96$. The test does not therefore conclude a significant difference of averages between the two groups.

\section{Financial equilibrium ratio:}

The Levene $\mathrm{p}$ is equal to 0.21 and the reading of the first line of the test $\mathrm{t}$ gives: $\mathrm{t}(116)=-0.64$ with $\mathrm{p}=0.5$. So the test is not conclusive to a significant difference of averages between the two groups.

\section{Reduced Liquidity and General liquidity:}

The Levene test gives $p=0$, and the reading of the second line of the test $t$ yields the following results: $t(5)=$ 1.33 with $\mathrm{p}=0.24$. So the test is not conclusive to a significant difference in means between the two groups.

\subsubsection{Empirical results of the t test for the Industry sector}

The following table presents descriptive statistics of structure and liquidity ratios within the industry sector.

Tableau 5: Industry sector descriptive statistics

\begin{tabular}{|l|l|l|l|l|l|}
\hline & Employee Shareholding & $\mathrm{N}$ & Average & Standard deviation & Error Average standard \\
\hline \multirow{2}{*}{$\begin{array}{l}\text { Degree of depreciation of } \\
\text { material assets }\end{array}$} & Yes & 3 & 62,290 & 8,262 & 4,770 \\
\cline { 2 - 6 } & No & 41 & 61,967 & 14,967 & 2,337 \\
& & & & \\
\hline \multirow{2}{*}{ Indebtedness } & Yes & 3 & 52,490 & 13,768 & 7,949 \\
\cline { 2 - 6 } & No & 41 & 48,793 & 24,578 & 3,838 \\
\hline Financial equilibrium & Yes & 3 & 1,220 &, 034 &, 020 \\
\cline { 2 - 6 } & No & 41 & 1,593 &, 891 &, 139 \\
\hline Financing of current assets & Yes & 3 &, 646 &, 249 &, 144 \\
\cline { 2 - 6 } & No & 41 &,- 012 & 2,417 &, 377 \\
\hline Financial independence & Yes & 3 & 52,490 & 13,768 & 7,949 \\
\hline
\end{tabular}


Employee Shareholding and the Opportunity Cost of Lending Funds: An Empirical Study in the...

\begin{tabular}{|l|l|l|l|l|l|}
\hline & No & 41 & 48,793 & 24,578 & 3,838 \\
\hline \multirow{2}{*}{ General liquidity } & Yes & 3 & 1,956 &, 404 &, 233 \\
\cline { 2 - 6 } & No & 41 & 2,370 & 1,240 &, 193 \\
\hline \multirow{2}{*}{ Reduced liquidity } & Yes & 3 & 1,476 &, 579 &, 334 \\
\cline { 2 - 6 } & No & 41 & 1,729 & 1,188 &, 185 \\
\hline
\end{tabular}

The above comparative table of descriptive statistics of enterprise groups within the Industry sector shows higher values for firms that engage in employee share ownership especially concerning the depreciation of tangible assets, net current assets and financial independence. In order to ensure these results, we carried out the Levene test and the $t$ test, the results of which are as follows:

\section{Degree of depreciation of material assets:}

From the table of the Levene test and the test $t$, we note that the $p$ of the Levene sig column is equal to 0.4 , we will then read the first line of the test $t$ of the equality of the variances which gives $t(42)=0.04$ with a $p$ of 0.97 . This degree of significance does not reject the null hypothesis according to which the average difference observed between the two groups is compatible with the population difference of 0 .

\section{Indebtedness ratio:}

The Levene test gives a $\mathrm{p}=0.37$ so the null hypothesis of the equality of the variances is maintained and we will then read the first line of the test $\mathrm{t}, \mathrm{t}(42)=0.26$ with $\mathrm{p}=0.8$. We deduce that the difference of the averages is compatible with the population difference of 0 .

\section{Financing of current assets :}

The Levene $p$ is equal to 0.6 and the reading of the first line of the test t gives: $t(42)=0.47$ with $p=0.64$. These results do not allow us to reject the null hypothesis.

\section{Financial independence :}

The Levene $p$ is equal to 0.37 and the first line of the test $t$ gives $t(42)=0.26$ with $p=0.8$. The test does not therefore conclude a significant difference of averages between the two groups.

\section{Financial equilibrium:}

The Levene $\mathrm{p}$ is equal to 0.23 and the reading of the first line of the test $\mathrm{t}$ gives: $\mathrm{t}(42)=-0.72$ with $\mathrm{p}=0.48$.

The test does not therefore conclude a significant difference of averages between the two groups.

\section{General liquidity ratio:}

The Levene test gives $\mathrm{p}=0,19$ and the reading of the second line of the test $\mathrm{t}$ yields the following results: $\mathrm{t}(42)$ $=-0.57$ with $\mathrm{p}=0.57$

So the test is not conclusive to a significant difference in averages between the two groups.

\section{Reduced liquidity ratio:}

The Levene test gives $p=0.44$ and the reading of the second line of the test t yields the following results: $\mathrm{t}(42)$ $=-0.36$ with $\mathrm{p}=0.72$

So the test is not conclusive to a significant difference in averages between the two groups.

\subsection{Test results from sample 2}

Sample No. 2 consists of pairs of equivalent enterprises, in terms of size and sector of activity. We obtained 10 pairs of companies in the Holding sector, 4 pairs in the Industry sector and 5 pairs in the Services sector. The following table presents the sectoral distribution of our sample.

Table 6: Frequencies by sector of activity

\begin{tabular}{|l|l|l|l|l|}
\hline Sector & Number & Pourcentage & Valid Pourcentage & Cumulative Pourcentage \\
\hline Holding & 20 & 52,6 & 52,6 & 52,6 \\
\hline Industry & 8 & 21,1 & 21,1 & 73,7 \\
\hline Services & 10 & 26,3 & 26,3 & 100,0 \\
\hline Total & 38 & 100,0 & 100,0 & \\
\hline
\end{tabular}

Each pair of companies is composed of two types of companies, one with employee shareholding and the other without employee shareholding. We then obtained 19 companies that practice employee ownership compared to 19 other companies belonging to a control group. The following table shows the number of companies classified by sector of activity. 
Employee Shareholding and the Opportunity Cost of Lending Funds: An Empirical Study in the...

Table 7: The sectoral distribution of firms within each category

\begin{tabular}{|l|l|l|l|l|}
\hline \multicolumn{3}{|l|}{ Division } & Nolding & 10 \\
\hline \multirow{3}{*}{ Employee Shareholding } & \multirow{3}{*}{0} & \multirow{3}{*}{ Sector } & Industry & 4 \\
\cline { 3 - 5 } & & Services & 5 \\
\cline { 4 - 5 } & \multirow{3}{*}{1} & \multirow{3}{*}{ Sector } & Holding & 10 \\
\cline { 4 - 5 } & & Industry & 4 \\
\cline { 3 - 4 } & & Services & 5 \\
\hline
\end{tabular}

The following table presents the descriptive statistics of the ratios making up the Altman score for our entire sample.

Table 8: Descriptive statistics of the ratios making up the Altman score for sample 2

\begin{tabular}{|l|l|l|l|l|l|}
\hline & $\mathrm{N}$ & Minimum & Maximum & Average & Standard deviation \\
\hline X1 & 38 &,- 116 &, 554 &, 185 &, 161 \\
\hline X2 & 38 &, 001 &, 691 &, 413 &, 1503 \\
\hline X3 & 38 &,- 060 & 1,369 &, 048 &, 223 \\
\hline X4 & 38 &, 00 & 5,11 &, 855 & 1,285 \\
\hline X5 & 38 &, 000 & 4,062 &, 364 &, 798 \\
\hline Altman Score & 38 &, 475 & 5,228 & 1,808 & 1,197 \\
\hline
\end{tabular}

The table shows that, for the ratio X1, the average of the sample is equal to 0.185 with a standard deviation of 0.161 . The average of the ratio X2 is equal to 0.413 with a minimum within the sample of 0.01 . The ratio X3 has an average lower of 0.048 with a negative minimum of -0.060 . The upper average is that of the ratio $\mathrm{X} 4$ which reaches the value of 0.855 with a maximum value of 5.11 . The average of the ratio X5 is equal to 0.364 and that of the Altman score is 1,808 .

\subsubsection{Résultats empiriques du test $t$ pour le secteur Holding}

Tableau 9: Les statistiques descriptives du score d'Altman au sein du secteur Holding

\begin{tabular}{|l|l|l|l|l|l|}
\hline & Employee Shareholding & N & Average & Standard deviation & Average Standard Error \\
\hline Altman Score & Yes & 10 & 1,785 & 1,003 &, 317 \\
\cline { 2 - 6 } & No & 10 & 1,921 & 1,343 &, 424 \\
\hline
\end{tabular}

The table above shows the existence of a higher average difference for companies that do not engage in employee share ownership.

From the table of the Levene test and the $\mathrm{t}$ test, it is noted that the $\mathrm{p}$ of the "sig" column of Levene is equal to 0.597 . The test is not significant and we keep the null hypothesis of the equality of the variances which is one of the premises of the test $t$.

We will then read the first line of the test $t$ of the equality of the variances which gives $t(-0,257)=18$ with a $p$ of 0,8 . This degree of significance does not reject the null hypothesis according to which the difference of average observed between the two groups is compatible with the population difference of 0 .

\subsubsection{Empirical results of the $t$ test for the Industry sector}

Table 10: Descriptive statistics of the Altman score within the Industry sector

\begin{tabular}{|l|l|l|l|l|l|}
\hline & Employee Shareholding & N & Average & Standard deviation & Average Standard Error \\
\hline \multirow{2}{*}{ Altman Score } & Yes & 4 & 2,541 & 1,713 &, 989 \\
\cline { 2 - 7 } & No & 4 & 2,191 & 2,032 & 1,016 \\
\hline
\end{tabular}

The table above shows the existence of a higher average difference for companies that engage in employee shareholdings in the Industry sector.

From the table of the Levene test and the t test, it can be seen that the p of the "sig" column of Levene is equal to 0.696 .

The test is not significant and we keep the null hypothesis of the equality of the variances which is one of the premises of the test of $t$.

We will then read the first line of the test $t$ of the equality of the variances which gives $t(0.240)=5$ with a p of 0.82. This degree of significance does not reject the null hypothesis according to which the difference of averages observed between the two groups is compatible with the population difference of 0 .

\subsubsection{Empirical Results of the t-Test in the Services Sector}

Table 11: Descriptive statistics of the Altman score within the Industry sector

\begin{tabular}{|l|l|l|l|l|l|}
\hline & Employee Shareholding & $\mathrm{N}$ & Average & Standard deviation & Average Standard Error \\
\hline \multirow{2}{*}{ Altman Score } & Yes & 5 & 1,007 &, 437 &, 195 \\
\cline { 2 - 7 } & No & 5 & 1,659 &, 871 &, 389 \\
\hline
\end{tabular}


The table shows the existence of a higher average difference for companies that do not engage in employee shareholding in the Services sector.

From the table of the Levene test and the t test, it can be seen that the p of the "sig" column of Levene is equal to 0.256 .

The test is not significant and we keep the null hypothesis of the equality of the variances which is one of the premises of the test of $t$.

We will then read the first line of the test $t$ of the equality of the variances which gives $t(-1,494)=8$ with a $p$ of 0,173 . This degree of significance does not reject the null hypothesis according to which the mean difference observed between the two groups is compatible with the population difference of 0 .

\section{5 t-test results for matched samples}

The matched sample method is used to examine the extent to which the sign and magnitude of the observed difference in Altman's score vary depending on whether the comparison relates to firms that engage in employee shareholding or not.

Table 12: Matched sample statistics

\begin{tabular}{|l|l|l|l|l|}
\hline & Average & $\mathrm{N}$ & Standard deviation & Average Standard Error \\
\hline Altman Score & 1,708 & 1 & 1,063 &, 244 \\
Employee Shareholding = 1 & & 9 & & \\
\hline Altman Score & 2,010 & 1 & 1,367 &, 313 \\
Employee Shareholding = 1 & & 9 & & \\
\hline
\end{tabular}

The table of matched sample statistics shows the existence of an average difference in favor of firms that do not engage in employee shareholding.

From the test table of the test $\mathrm{t}$, we note that $\mathrm{t}(-0.988)=18$ with a $\mathrm{p}$ of 0.336 .

This degree of significance does not reject the null hypothesis that the mean difference observed between the two groups is compatible with the population difference of 0 .

\section{Conclusion}

In a financial framework, the hypothesis $\mathrm{H} 1$ of our study argues that the trust created by employee share ownership makes it possible to reduce the opportunity costs of the lenders. To test this hypothesis we have conducted two empirical studies. The first is to study the structural and liquidity ratios of the SBF 250 companies on a longitudinal sample from 2001 to 2009. The second study consists of comparing, on a crosssectional matched sample, the Altman score of 19 business pairs.

The results of the tests of comparisons of averages do not make it possible to corroborate the hypothesis H1. Indeed, the statistical tests carried out reveal that a sustained employee share ownership policy, within the meaning of the Federation of Employee Shareholders' Associations and former Employees, does not translate into an improvement in the structure and liquidity ratios and the Score of Altman.

These results were confirmed despite the use of a longitudinal study covering the period 2001-2009 and the creation of a sample composed of two subsets: a subset comprising companies with a strong employee shareholding policy And a subset comprising companies without employee shareholdings, equivalent in terms of size and sector of activity.

We believe that the non-significance of the statistical results is attributed to the composition of the Euronext FAS IAS Index. It is a variable index that changes every quarter, and the financial indicators considered are calculated on an annual basis. The purpose of these indicators is to judge the financial health of firms for a given fiscal year and from the elements of the past. It is then to study the past to diagnose the present and foresee the future. (Vernimmen 1998, p.162).

According to the criteria established for the calculation of the Euronext FAS IAS Index, a company may co-exist on the two groups over the year: the group with employee shareholding and the group without employee shareholding. We believe that this variability has prevented our study from basing a reliable judgment on the ratios and scores of the companies studied.

\section{References}

[1]. Allouche J., Amann, B., Garaudel, P. (2008), «Performances et caractéristiques financières comparées des entreprises familiales et non familiales : le rôle modérateur de la : cotation en bourse et du degré de contrôle actionnarial », Journal des Entreprises Familiales $n^{\circ}$ 1, p. 5-39.

[2]. Allegret, J.P., Baudry, B. (1996), «La relation banque-entreprise: structures de gouvernement et formes de coordination », Revue Française d'Economie, ${ }^{\circ} 11(4)$, p. 3-36.

[3]. Altman, E. (1968), «Financial ratios, discriminant analysis and the prediction of corporate bankruptcy », The Journal of Finance, $\mathrm{n}^{\circ}$ 23(4), p. 589-609.

[4]. Bardos, M. (2001), Développements récents de la méthode des scores de la Banque de France ,Bulletin de la Banque de France. 
Employee Shareholding and the Opportunity Cost of Lending Funds: An Empirical Study in the...

[5]. Barber, B. (1983), The logic and limits of trust, New Brunswick, N.J: Rutgers University Press.

[6]. Beaver, W. (1966), « Financial ratios as predictors of failure », Journal of Accounting Research », n 5, p. 71-111.

[7]. Bernanke, B., Gertler, M. (1990), «Financial fragility and economic performance », The Quaterly Journal of Economics, $\mathrm{n}^{\circ}$ 105(1), p. $87-114$.

[8]. Blackwell, D., Winters, D. (1997), «Banking Relationships and the Effect of Monitoring on Loan Pricing», Journal of Financial Research, $\mathrm{n}^{\circ}$ 20(2), p. 275-289.

[9]. Bloch, L., Bourdieu J., Collin-Sedillot, B., Longueville, G. (1994), Du défaut de paiement au dépôt de bilan: les banquiers faces aux P.M.E en difficulté. INSEE, Série des Documents de Travail du Département des Etudes Economiques d'Ensemble et du Département de la conjoncture.

[10]. Calomiris, W., Hubbard, R. (1990), « Firm Heterogeneity.Internal Finance, and Credit

[11]. Rationing », Economic Journal, nº 100 (399), p. 90-104.

[12]. Canella, A. (1995), «Executives and Shareholders: a Shift in the Relationship», Human Resource Management, p. 166184.

[13]. Charreaux, G. (1998), « Le rôle de la confiance dans le système de gouvernance des entreprises », Economies et Sociétés, $\mathrm{n}^{\circ}(8-9)$, p. 47-65.

[14]. Charreaux, G., Desbrières, P. (1998), « Gouvernance des entreprises : valeur partenariale contre valeur actionnariale », Finance Contrôle Stratégie, $\mathrm{n}^{\circ} 1(2)$, p. 57-88.

[15]. Conan J., Holder, M. (1979), «Variables explicatives de performances et contrôle de Gestion dans les PMI », Thèse de doctorat en sciences de gestion, Université Paris Dauphine.

[16]. Crutzen, N., Van Caillie, D. (2007), L'enchaînement des facteurs de défaillance de l'entreprise: une réconciliation des approches organisationnelles et financières, XXVIIIe Congrès annuel de l'Association française de comptabilité, Poitiers.

[17]. Diamond, D. (1989), « Reputation Acquisition in Debt Markets », Journal of Political Economy, n 97(4), p. 828-862.

[18]. Elouadi, S. (2014). Analyse des effets induits par l'actionnariat salarié sur la création de valeur partenariale des entreprises du SBF 250. Thèse de doctorat Toulon.

[19]. Elouadi, S. (2015). Les effets attitudinaux de l'actionnariat salarié: une étude empirique dans le contexte des entreprises françaises du SBF 250. Question ( $s$ ) de management, (3), 11-24.

[20]. Elouadi, S., Noamene, T. B., \& Chaher, D. (2016). Employee Ownership And Employee-Shareholders Satisfaction: An Analysis Of French Companies Listed On The SBF 250. Journal of Applied Business Research (JABR), 32(3), 981-994.

[21]. Farmer, R.E. (1985), "Implicit contracts with asymmetric information and bankruptcy: the effect of interest rates on LayOffs », Review of Economic Studies, $n^{\circ}$ 52, p. 42-442.

[22]. Fishman, R., Khanna, T. (1999), «Is trust a historical residue? Information flows and trust levels », Journal of Economic Behavior and Organization, $n^{\circ} 38(1)$, p. 79-92.

[23]. Gilles, P. (1992), «Incertitude, risque et asymétrie d'information sur les marchés financiers », Revue française d'économie, $n^{\circ}$ 1(2), p. $55-115$

[24]. Harhoff, D., Korting, T. (1998), «Lending relationships in Germany- Empirical evidence from survey data », Journal of Banking and Finance, $n^{\circ} 22$, p. 10-11.

[25]. Jullien, H., Paranque, B. (1995), « Financement des entreprises et évolution du système financier », Revue Internationale $P M E, n^{\circ}$ 8,p. 43-66.

[26]. Kreps, D. (1990), Corporate culture and economic theory, In perspectives on positive political economy (Eds, Alt, J.E., Shepsle, K.A.). New York: Cambridge University Press, p. 90-143.

[27]. La Bruslerie, (de) H. (1999), Analyse financière et risque de crédit, Paris : Dunod.

[28]. Lehmann, E., Neuberger, D. (2001), « Do lending relationships matter ? Evidence from bank survey data in Germany », Journal of Economic Behavior and Organization , $\mathrm{n}^{\circ}$ 45(4),p. 339-359.

[29]. Levratto, N. (1996), Poids des asymétries informationnelles et de l'aléa de moralité dans les relations entre banques et PME , 3ème Congrès International Francophone sur les PME, Québec.

[30]. Luhmann, N. (1979), Trust and Power - Two works, Great Britain: John Wiley \& Sons Ltd, Pitman Press.

[31]. Lewicki, R.J., Bunker, B.B. (1996), Developing and maintaining trust in work relationships. In Trust in Organisations : Frontiers of Theory and Research (Eds, Kramer, R.M., Tyler, T.R.). Thousand Oaks, CA: Sage, 114-139.

[32]. Neveu, V. (2004),La confiance organisationnelle : définition et mesure, Actes du XVème congrès de l'AGRH, Montréal.

[33]. Opler, T.C., Titman, S. (1994), « Financial Distress and Corporate Performance », Journal of Finance 49(3): 1015-1040.

[34]. Pastena, V., Ruland, W. (1986), « The merger / Bankruptcy», Accounting Review, n 61, p. 288- 301.

[35]. Rousseau, D.M., Sitkin, S.B., Burt, R.S., Camerer, C. (1998), « Not so different after all: a cross- discipline view of trust », Academy of Management Review, $n^{\circ} 23$, p. 393-404.

[36]. Shapiro, D., Sheppard, B.H., Cheraskin, L. (1992), « Business on a handsake », Negotiation Journal, $n^{\circ}$ 8, p.365-377.

[37]. Stiglitz, J.E. (1989), «The Development of Financial Markets for Economic Development », The Economic Reconstruction of Latin America, Rio de Janeiro.

[38]. Thiétart, R.A et Coll. (1999). Méthodes de Recherche en Management. Paris : Dunod.

[39]. Van Caillie, D. (2000), La détection des signaux financiers annonciateurs de faillite en contexte PME : une approche méthodologique spécifique, In AIREPME, Actes du 5ème Congrès International Francophone sur la PME.

[40]. Vernimmen, P., Quiry, P., Ceddaha F. (1998), Finance d'entreprise. 3ème édition, Paris : Dalloz.

[41]. Williamson, O.E. (1985), The Economic Institutions of Capitalism. New York: The Free Press.

[42]. Wruck, K.H. (1990), «Financial distress, reorganization, and organizational efficiency, Journal of Financial Economics », n 27(2), p. 419-444.

[43]. Zucker, L. (1986), «Production of trust: institutional sources of economic structure: 1840-1920», Research in Organization Behaviour, n ${ }^{\circ}$, p. 53-111. 